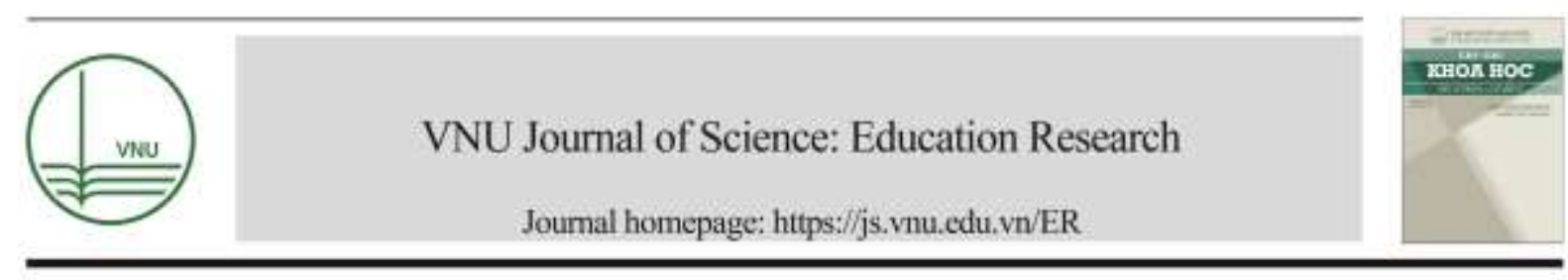

Original Article

\title{
Educational Benefits of Kahoot! in Enhancing Skills: Investigating Students' Perspectives
}

\author{
Le Nguyen Ai Nhan, Kieu Thi Thu Trang, Nguyen Thi Quyen* \\ HCMC University of Economics and Finance, \\ 145 Dien Bien Phu, Binh Thanh, Ho Chi Minh City, Vietnam \\ Received 8 August 2021 \\ Revised 28 September 2021; Accepted 29 September 2021
}

\begin{abstract}
This study focuses on exploring the contribution of Kahoot! to students' skill enhancement. We set out to determine students' perceived judgments on how much their skills have improved as a result of using Kahoot! inside classrooms. Deviating from several related research, we not only looked at the effects of playing Kahoot! games but also of creating Kahoot! games. Using a survey that takes Bloom's taxonomy as its theoretical foundations, we elicited judgments from 95 university freshmen, sophomores, and juniors. Students' self-reports were analyzed using a series of one-way repeated measures ANOVA, which reveals a number of interesting results. First, students reported significant skill improvement when they played Kahoot! during class and even more so when they themselves were involved in the creation of Kahoot! games. Second, not all of the examined skills are subject to the same degree of improvements, leaving some room for educators to ponder how they can use gamification to effectively develop students' comprehensive skill set. Thirdly, freshmen and juniors reported the highest amount of skill improvements, indicating that certain game-based applications might be helpful for only certain groups of students. Taken together, we suggest that Kahoot! games can be utilized in classrooms for both knowledge enhancement and effective skill improvement.
\end{abstract}

Keywords: Kahoot, educational benefit, game-based, skill, skill improvement.

\section{Introduction}

In the new digital era, every aspect of life has been dramatically transformed. People have been making use of technological advancements to greatly facilitate a range of sectors such as communication, logistics,

\footnotetext{
* Corresponding author.

E-mail address: quyennt@uef.edu.vn

https://doi.org/10.25073/2588-1159/vnuer.4558
}

marketing, among other things. Education is obviously not an exception, especially when it comes to the question of how technological innovations can be integrated into language teaching and learning. The passive traditional language classrooms in which standard curriculums are imparted to students by teachers, and students are required to finish their homework, or learn by heart the previous lessons at home in order to acquire knowledge have now been replaced by the modern ones. 
This can be seen in the proliferation of new educational strategies and initiatives, and innovative methodologies such as Flipped Classroom or Game-Based Learning are implemented inside classrooms in many higher learning institutions.

Particularly, there is an increasing number of university lecturers who utilize the gamification in their teaching process to foster students' engagements, facilitate the students' acquisition of knowledge as well as enhance their skills. Pachler, Bachmair and Cook (2010) [10] set out to investigate the impact of the gamification approach in classrooms through the use of Kahoot! as an interactive game-based system. Results from this study have pointed to a number of positive effects of using Kahoot! including increased classroom involvement. From then on, Kahoot! has become one of the most innovative and widely used platforms where language education meets technology.

Kahoot!, which is monthly used by 70 million worldwide active users (Wang and Tahir, 2020) [14], is highlighted as "a popular e-learning tool that can be easily used for providing metacognitive support, liveliness in class and student attendance in higher education which need limited lecturers and student education" (Bicen and Kocakoyun, 2018) [1]. Thanks to its numerous advantages, this game-based learning system has been widely adopted as either a review tool, a formative assessment method, or simply a break from traditional classroom activities in a variety of disciplines such as natural science subjects and social science subjects.

Despite the breadth of research into the educational benefits of using gamification inside classrooms, there has not been any research that looks into the beneficial effects of Kahoot! in terms of skill enhancement from students' perspective. In addition, most research is primarily concerned with the effects of game-based activities in which students take the role of players, thus enabling only the examination of the effects from playing the games only while little is known about those effects when students take more active roles.
Given the recent promotion of learner-centred classrooms, it is important to look at how students develop their skills when given more authority in classroom activities, i.e., being a creator and/or a moderator. This study is therefore set out to touch on these questions.

The current study aims at finding out the educational benefits of using Kahoot! in enhancing students' skill sets and investigating the perception of students who are involved in playing and creating Kahoot!-based activities as to how much their skills improve through those activities. To this end, the current study seeks to answer the following research questions:

Research question 1: to what extent do Kahoot! game-based activities contribute to skill enhancement as perceived by students?

Research question 2: what factors may account for students' variability in their judgments on skill improvement as a result of Kahoot! game-based activities?

To our knowledge, this study is the first attempt to investigate these issues. Therefore, the findings of this research are hoped to provide educators, especially university lecturers, with critical findings regarding the use of gamification in classrooms. In addition, the current study incorporates Bloom's taxonomy into its theoretical foundations, using this theoretical framework to develop our own research instrument that surveys into the beneficial aspects of gamification in education. Consequently, further studies which aspire to research on the same phenomenon can adopt and modify our instruments, thus enabling comparisons of results, validating the instrument as well as enriching our knowledge regarding new technologically integrated approaches in education.

\section{Literature Review}

\subsection{Skills in Educational Contexts}

The word "skill" is linguistically defined as an ability to do something well. From a theoretical standpoint, the concept of "skill" is 
initially depicted as a 3-level hierarchy comprising the cognitive domain, the affective domain, and the psychomotor domain in Bloom's taxonomy (Bloom, 1956) [2]. Furthermore, Kechagias (2011) [5] highlights that skills are unstable (personal) traits which can be learned, developed and demonstrated in specific circumstances. For individuals to acquire and to perform their skills, besides possessing innately gifted personal attributes, they need to comprehend the fundamental knowledge, know how to go about with suitable attitudes, be encouraged to act, and be put in compatible circumstances which allow their performances to be carried out.

In fact, there are a variety of skills which a person may possess to demonstrate in working or studying. Those also have been categorized into different classifications based on typical features, diverse theoretical frameworks, or perspectives. In order to exhaustively indicate specific items related to skills which tertiary education learners can gain from Kahoot! in the instrument of this study, the researchers adopt the following frameworks:

The Lists of Six Elements (NCVER, 2003) [8]:

i) Basic/fundamental skills-such as literacy, using numbers, using technology;

ii) People-related skills-such as communication, interpersonal, teamwork, customer service skills.

iii) Conceptual/thinking skills-such as collecting and organizing information, problem solving, planning, and organizing, learning-to-learn skills, thinking innovatively and creatively, systems thinking;

iv) Personal skills and attributes-such as being responsible, resourceful, flexible, able to manage one's own time, having self-esteem.

v) Skills related to the business world-such as innovation skills, enterprise skills;

vi) Skills related to the community-such as civic or citizenship knowledge and skills.

Bloom's Taxonomy: the Psychomotor Domain (Bloom, 1956) [2]:

i) Perception-the ability to use sensory cues to guide motor activity: this ranges from sensory stimulation, through cue selection, to translation.

ii) Set-Readiness to act: it includes mental, physical, and emotional sets. These three sets are dispositions that predetermine a person's response to different situations (sometimes called mindsets). This subdivision of psychomotor is closely related with the "responding to phenomena" subdivision of the affective domain.

iii) Guided response-the early stages of learning a complex skill that includes imitation and trial and error: adequacy of performance is achieved by practicing;

iv) Mechanism-the intermediate stage in learning a complex skill: learned responses have become habitual and the movements can be performed with some confidence and proficiency;

v) Complex overt response-the skillful performance of motor acts that involve complex movement patterns: proficiency is indicated by a quick, accurate, and highly coordinated performance, requiring a minimum of energy. This category includes performing without hesitation and automatic performance;

vi) Adaptation-skills are well developed, and the individual can modify movement patterns to fit special requirements;

vii) Origination-creating new movement patterns to fit a particular situation or specific problem: learning outcomes emphasize creativity based upon highly developed skills.

This paper focuses on the probability of skills improvement in students through making Kahoot! in classes. In an academic setting, learning skills are the vital asset needed for students to succeed in university and beyond. To be more specific, we divided learning skills into three main skills which are creativity skills, problem solving skills, and analytical skills. The definition of these skills is still too broad and might be interpreted differently among people. This leads us to simplify them into actions. Nevertheless, within one skill, an interpreted action can combine different levels of cleverness from the simplest to the most complex (i.e., creating Kahoot! games, from 
adding visuals (the simplest action) to adding audio (a more complex one). Therefore, the need for a classifier is available and psychomotor domain helps to categorize actions into the corresponding class.

\subsection{Related Studies on the Benefits of Game-based Activities}

The use of student response systems (SRSs) is phenomenally popular in higher education and has been adopted as an educational medium in many disciplines such as biology, chemistry, mathematics, physics, computer science, business, psychology. SRSs have also received positive perception of both students and instructors (Nguyen and Yukawa, 2019) [12]. The SRSs typical pattern allows instructors to pose questions and students can respond immediately through handheld gadgets such as smartphones or touch-screen devices. In the proliferation of the Internet, the Bring Your Own Device (BYOD) wave allows students with easy access to mobile instruments and the infrastructure advancement in learning technology facilitating the use of gamification in educational context. Thus, there have been several studies regarding the efficacy of game-based learning such as students' engagement, increasing self-efficacy, and reducing anxiety.

In a study of Wang and Tahir in 2020 [14], her team investigated the effect of this amalgamation through analyzing the publications related to Kahoot!. The results indicate that using Kahoot! as a supporting tool in non-traditional classroom results in significantly better performance of students in the final assessment, the use of Kahoot! also reduces the reluctance of students to participate more in classes, reduces student anxiety and raises the confidence level.

Another quasi-experiment consisted of 98 undergraduate tertiary students attending the same nursing course divided into two groups: the experimental group and the control group. After four 20-minute sessions of Kahoot! implementation, the results indicated that the experimental group had significant higher final examination scores (Kinder and Kurz, 2018) [6]. Other studies which investigated the students' engagement aspect of Kahoot! showed that $98,2 \%$ of students preferred the use of Kahoot in classes, and $100 \%$ agreed that they permeated more in classes as Kahoot! created an interactive atmosphere (Plump and LaRosa, 2017) [11]. In addition, $93 \%$ of students were more willing to interact with their peers and instructors as well as involve themselves in class activities (Licorish et al., 2018) [7]. In terms of students' anxiety, both teachers and students gave positive feedback about the utilization of Kahoot compared to the reminiscent platform Socrative (Turan and Meral, 2018) [13] or traditional classroom (Budiati, 2017) [3] although initially, teachers assumed that Kahoot! heightened the anxiety level based on the stereotype image of Kahoot! as a competitive game (Wang and Tahir, 2020) [14]. Finally, another study conducted in 2018 revealed that Kahoot! boosted the confidence level of $66 \%$ of the total students participating in the survey (Tsymbal, 2018) [12].

Besides the benefits, there are drawbacks relating to the use of Kahoot including the classroom dynamics might be subdued when using Kahoot! continually. Furthermore, it is also found that the time limit on each question causes the students to answer as quickly as they can without any knowledge reinforcement (Bicen and Kocakoyun, 2018) [1].

Although many studies have clarified the effects of Kahoot! on both sides-the positive and the negative, most of them only focus on the cognitive understanding, the involvement, the apprehension, and the confidence of students. There is only a dearth of empirical evidence concerning how Kahoot! in the classroom might impact the development of skills available. This research, therefore, aims to fill this gap by trying to determine whether Kahoot! contributes to the skills enhancement of students.

\section{Methodology}

\subsection{Setting and Participants}


The study was conducted within the Faculty of English at a university in Ho Chi Minh city. The participants of this research were 100 students including 30 freshmen, 23 sophomores, and 47 juniors. The number of students joining Kahoot! games in class at least once account for $95 \%$. Additionally, $68.4 \%$ of those 95 students have created Kahoot! games to use for their activities in classes since most lecturers in this university often give their students opportunities to take over the classes in a short period of time to make presentations or peer tutoring activities.

Each student was asked whether he/she had ever joined any Kahoot! games in class and had ever designed any Kahoot! games themselves. The specific number of participants responding to the questions is illustrated in Table 1 below.

Table 1. Number of respondents

\begin{tabular}{|l|l|l|l|}
\hline & $\begin{array}{l}\text { Partici-pants } \\
(\mathrm{N})\end{array}$ & $\begin{array}{l}\text { Playing } \\
\text { Kahoot! } \\
(\mathrm{N})\end{array}$ & $\begin{array}{l}\text { Making } \\
\text { Kahoot! } \\
(\mathrm{N})\end{array}$ \\
\hline First year & 30 & 29 & 15 \\
\hline $\begin{array}{l}\text { Second } \\
\text { year }\end{array}$ & 23 & 19 & 13 \\
\hline $\begin{array}{l}\text { Third } \\
\text { year }\end{array}$ & 47 & 47 & 37 \\
\hline & 100 & 95 & 65 \\
\hline
\end{tabular}

\subsection{Data Collection}

A closed-ended questionnaire consists of 3 sections, namely Background information, Playing Kahoot!, and Creating Kahoot!. The participants went through each section respectively until they finished the survey. Beginning with a multiple-choice question about when the teachers let the participants play Kahoot! games during class and culminating with one about whether they have ever made any Kahoot! games, the Playing Kahoot! section contains a list of 17 items assessed by using a five-point Likert scale (1 means "Not at all" and 5 means "Very much"). Each item illustrates a specific skill which the participants can gain/develop from playing games of this learning tool and is indicated based on the lists of six elements (NCVER, 2003) [8]. The Creating Kahoot! section also comprises 16 items matching with 16 skill-interpreted actions gained from making Kahoot! games. The participants again rated each item on a Likert scale from 1 to 5 where 1 indicates no improvement at all and 5 indicates that they have improved their skills very much. These items were designed based upon Bloom's taxonomy: The psychomotor domain (Bloom, 1956) [2].

The questionnaire was constructed using Google Forms. It then was distributed to the English-major students via emails or by students scanning QR codes.

\subsection{Data Analysis Method}

The gathered data was exported to Excel and refined before analysis. The researchers eliminated respondents who said they had never played Kahoot!, leading to the remaining 95 valid responses. The average score of each item and each skill set was then calculated. Researchers classified the data based on the students' year and group skills. These sets of data were subjected to several one-way repeated measures ANOVAs using the software program SPSS 20 for Windows.

\section{Findings}

\subsection{Educational Benefits Gained from Playing Kahoot}

Table 2 below provides descriptive statistics of students' ratings of their perceived improvement of skills. On the whole, the mean score of each item fluctuates from 3.41 to 4.2 points, indicating that the majority of participants consider they do improve every stated skill after playing Kahoot! games. Regarding the people-related skills group, among 7 items, the "You can patiently listen to your teammates' ideas while discussing the answers" item accounts for the highest score $(\mathrm{M}=4.15 ; \mathrm{SD}=0.92)$. In the conceptual/ thinking skills group, it can be seen that "You can identify connections between acquired 
knowledge and questions to choose the correct answers" item is rated with the highest score $(\mathrm{M}=3.88 ; \mathrm{SD}=0.78)$. With respect to the 6-item personal skills and attributes group, the "You can enthusiastically contribute your ideas to the team" item receives the highest ratings, at 3.98 points $(\mathrm{SD}=0.90)$.

Table 2. Descriptive statistics of students' ratings of improvement regarding skills gained from playing Kahoot!

\begin{tabular}{|c|c|c|}
\hline & Items & $\begin{array}{l}\text { Mean } \\
(\mathrm{SD})\end{array}$ \\
\hline \multirow{7}{*}{ 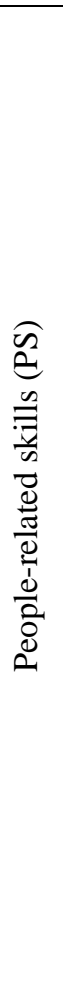 } & $\begin{array}{l}\text { You can quickly team up with } \\
\text { people when being asked to play } \\
\text { in team mode. }\end{array}$ & $\begin{array}{l}3.73 \\
(1.06)\end{array}$ \\
\hline & $\begin{array}{l}\text { You can handle any conflicts } \\
\text { between you and your teammates } \\
\text { when playing in team mode. }\end{array}$ & $\begin{array}{l}3.63 \\
(0.96)\end{array}$ \\
\hline & $\begin{array}{l}\text { You can discuss with your } \\
\text { teammates effectively to find the } \\
\text { correct answers while playing in } \\
\text { team mode. }\end{array}$ & $\begin{array}{l}3.91 \\
(0.91)\end{array}$ \\
\hline & $\begin{array}{l}\text { You can motivate your teammates } \\
\text { to keep going even when your } \\
\text { team is falling behind. }\end{array}$ & $\begin{array}{l}3.72 \\
(1.00)\end{array}$ \\
\hline & $\begin{array}{l}\text { You can patiently listen to your } \\
\text { teammates' ideas while discussing } \\
\text { the answers. }\end{array}$ & $\begin{array}{l}4.15 \\
(0.92)\end{array}$ \\
\hline & $\begin{array}{l}\text { In case you surely know the } \\
\text { correct answers, you can } \\
\text { assertively persuade your } \\
\text { teammates to use your answers. }\end{array}$ & $\begin{array}{l}4.02 \\
(0.85)\end{array}$ \\
\hline & $\begin{array}{l}\text { You can ask your teammates } \\
\text { who remain silent to contribute } \\
\text { their ideas. }\end{array}$ & $\begin{array}{l}3.53 \\
(1.09)\end{array}$ \\
\hline \multirow{4}{*}{ 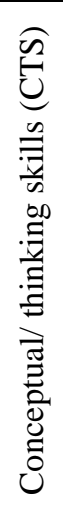 } & $\begin{array}{l}\text { You quickly find out the key } \\
\text { words in the questions. }\end{array}$ & $\begin{array}{l}3.84 \\
(0.93)\end{array}$ \\
\hline & $\begin{array}{l}\text { You quickly understand the main } \\
\text { ideas of the questions in a short } \\
\text { period of time. }\end{array}$ & $\begin{array}{l}3.80 \\
(0.87)\end{array}$ \\
\hline & $\begin{array}{l}\text { You can identify connections } \\
\text { between acquired knowledge } \\
\text { and questions to choose the } \\
\text { correct answers. }\end{array}$ & $\begin{array}{l}3.88 \\
(0.78)\end{array}$ \\
\hline & $\begin{array}{l}\text { You are able to adjust your } \\
\text { strategies for better results in the } \\
\text { next Kahoot! game. }\end{array}$ & $\begin{array}{l}3.87 \\
(0.90)\end{array}$ \\
\hline
\end{tabular}

\begin{tabular}{|c|c|c|}
\hline \multirow{6}{*}{ 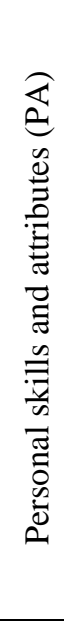 } & $\begin{array}{l}\text { You can enthusiastically } \\
\text { contribute your ideas to the team. }\end{array}$ & $\begin{array}{l}3.98 \\
(0.90) \\
\end{array}$ \\
\hline & $\begin{array}{l}\text { You can quickly give } \\
\text { the right answers. }\end{array}$ & $\begin{array}{l}3.61 \\
(0.91)\end{array}$ \\
\hline & $\begin{array}{l}\text { You are able to handle more than } \\
\text { one task at a time. }\end{array}$ & $\begin{array}{l}3.51 \\
(1.00)\end{array}$ \\
\hline & $\begin{array}{l}\text { Your hands-eyes coordination } \\
\text { gets better. }\end{array}$ & $\begin{array}{l}3.84 \\
(0.96)\end{array}$ \\
\hline & $\begin{array}{l}\text { You are not discouraged to keep } \\
\text { going even when you are falling } \\
\text { behind while playing. }\end{array}$ & $\begin{array}{l}3.65 \\
(1.05)\end{array}$ \\
\hline & $\begin{array}{l}\text { You are not disheartened even } \\
\text { when there is nobody listening to } \\
\text { your opinions. }\end{array}$ & $\begin{array}{l}3.37 \\
(1.19) \\
\end{array}$ \\
\hline & $\begin{array}{c}\text { OVERALL WEIGHTED } \\
\text { MEAN ITEMS }\end{array}$ & 3.11 \\
\hline
\end{tabular}

In order to make statistical inference and to test statistical significance of the main effects, a one-way repeated measures ANOVA was conducted, using three skill sets namely people-related skills, conceptual/thinking skills, personal skills and attributes as within-subjects factors, and the year which participants are in as between-subjects factors. The results of the repeated-measures ANOVA test are given in Table 3 below.

Table 3. Tests of Within-Subjects Effects

\begin{tabular}{|l|l|l|}
\hline Effects & $F$-value & $p$-value \\
\hline Group skill & $\begin{array}{l}F(1.934,177.897) \\
=5.612\end{array}$ & $p=0.005$ \\
\hline $\begin{array}{l}\text { Group skill * } \\
\text { Year }\end{array}$ & $\begin{array}{l}F(3.867,177.897) \\
=1.512\end{array}$ & $p=0.202$ \\
\hline
\end{tabular}

As shown in Table 3, the participants' perceived judgment about skill improvement between three skill sets is significantly different. In order to see where exactly the difference lies, we conducted pairwise comparisons between three groups of skills and presented results in Table 4 below.

It can be clearly seen in Table 5 above that there is a significant difference in the perceived judgment about skill improvement between the people-related skills group and the personal skills/attributes group $(p=0.038)$, between the conceptual/thinking skills group and the 
personal skills/attributes group $(p=0.000)$, but no significant differences between the people-related skills group and the conceptual/thinking skills group $(p=0.374)$.

Table 4. Pairwise Comparisons between three skill groups gained from playing Kahoot!

\begin{tabular}{|l|l|l|l|l|}
\hline \multicolumn{4}{|l|}{ Measure: MEASURE_1 } \\
\hline $\begin{array}{l}\text { (I) } \\
\begin{array}{l}\text { Group } \\
\text { skill }\end{array}\end{array}$ & $\begin{array}{l}\text { (J) } \\
\text { Group } \\
\text { skill }\end{array}$ & $\begin{array}{l}\text { Mean } \\
\text { Diff } \\
(\mathrm{I}-\mathrm{J})\end{array}$ & SE & Sig. \\
\hline PS & CTS & -0.049 & 0.055 & 0.374 \\
\hline & PA & $0.132^{*}$ & 0.063 & 0.038 \\
\hline CTS & PS & 0.049 & 0.055 & 0.374 \\
\hline & PA & $0.181^{*}$ & 0.049 & 0.000 \\
\hline PA & PS & $-0.132^{*}$ & 0.063 & 0.038 \\
\hline & CTS & $-0.181^{*}$ & 0.049 & 0.000 \\
\hline \multicolumn{7}{|c}{$p<0.05$} \\
\hline
\end{tabular}

With regard to the tests of between-subjects effects, the differences in the perception toward skills gained from playing Kahoot! games between the students in each year are not statistically significant, $F(2,92)=1.221, p=0.3$ $(p>0.05)$.

\subsection{Educational Benefits Gained from Creating Kahoot!}

Table 5 below summarizes the number of students and their corresponding ratings for each of the questionnaire items, along with the mean score for those items.

Table 5. Descriptive Statistics of students' ratings of improvement regarding skills gained from making Kahoot!

\begin{tabular}{|c|c|c|}
\hline & Items & $\begin{array}{l}\text { Mean } \\
(\mathrm{SD})\end{array}$ \\
\hline \multirow{2}{*}{ 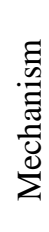 } & $\begin{array}{l}\text { You can stick to your plan to } \\
\text { finish making Kahoot! } \\
\text { games on time. }\end{array}$ & $\begin{array}{l}4.00 \\
(0.83)\end{array}$ \\
\hline & $\begin{array}{l}\text { You can organize questions in a } \\
\text { logical order. }\end{array}$ & $\begin{array}{l}3.91 \\
(0.96)\end{array}$ \\
\hline
\end{tabular}

\begin{tabular}{|c|c|c|}
\hline $\begin{array}{l}0 \\
0 \\
0 \\
0 \\
0 \\
0\end{array}$ & $\begin{array}{l}\text { You can create Kahoot! games } \\
\text { with visually appealing features. }\end{array}$ & $\begin{array}{l}4.03 \\
(0.85)\end{array}$ \\
\hline $\begin{array}{l}\overrightarrow{\vec{a}} \\
\times \\
x\end{array}$ & $\begin{array}{l}\text { You can efficiently allocate time } \\
\text { for answering each question. }\end{array}$ & $\begin{array}{l}4.02 \\
(0.74)\end{array}$ \\
\hline$\overline{\tilde{g}}$ & $\begin{array}{l}\text { You can host } \\
\text { the games charmingly. }\end{array}$ & $\begin{array}{l}3.85 \\
(0.97)\end{array}$ \\
\hline & $\begin{array}{l}\text { You can write questions using } \\
\text { accessible language that is easy } \\
\text { for everyone to understand. }\end{array}$ & $\begin{array}{l}3.98 \\
(0.96)\end{array}$ \\
\hline 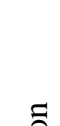 & $\begin{array}{l}\text { You can find reliable sources } \\
\text { to gather information about } \\
\text { the topic. }\end{array}$ & $\begin{array}{l}4.05 \\
(0.84)\end{array}$ \\
\hline 胥 & $\begin{array}{l}\text { You can ensure the validity } \\
\text { of the sources where you collect } \\
\text { the information. }\end{array}$ & $\begin{array}{l}3.98 \\
(0.89)\end{array}$ \\
\hline & $\begin{array}{l}\text { You can provide constructive } \\
\text { criticism when other members } \\
\text { ask you to check their parts. }\end{array}$ & $\begin{array}{l}3.92 \\
(0.85)\end{array}$ \\
\hline & $\begin{array}{l}\text { You can persuasively explain the } \\
\text { correct answers. }\end{array}$ & $\begin{array}{l}3.97 \\
(0.79)\end{array}$ \\
\hline \multirow{7}{*}{ 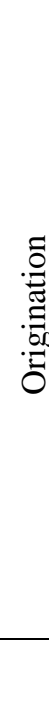 } & $\begin{array}{l}\text { You can make questions from } \\
\text { detailed information. }\end{array}$ & $\begin{array}{l}4.15 \\
(0.75)\end{array}$ \\
\hline & $\begin{array}{l}\text { You can apply prior knowledge } \\
\text { to create Kahoot! questions. }\end{array}$ & $\begin{array}{l}4.05 \\
(0.84)\end{array}$ \\
\hline & $\begin{array}{l}\text { You can combine knowledge } \\
\text { from different disciplines to } \\
\text { create Kahoot! questions. }\end{array}$ & $\begin{array}{l}3.92 \\
(0.87)\end{array}$ \\
\hline & $\begin{array}{l}\text { You can draw out an outline } \\
\text { before creating Kahoot! }\end{array}$ & $\begin{array}{l}3.98 \\
(0.99)\end{array}$ \\
\hline & $\begin{array}{l}\text { You can create Kahoot! games } \\
\text { with compatible audio materials. }\end{array}$ & $\begin{array}{l}3.91 \\
(1.01)\end{array}$ \\
\hline & $\begin{array}{l}\text { You can create a game-based } \\
\text { presentation. }\end{array}$ & $\begin{array}{l}4.11 \\
(0.83)\end{array}$ \\
\hline & $\begin{array}{l}\text { OVERALL WEIGHTED } \\
\text { MEAN ITEMS }\end{array}$ & 3.99 \\
\hline
\end{tabular}

Overall, the students agreed with the listed skills and Kahoot! creation is likely very helpful at sharpening their skills as the overall weighted mean of all items is 3.99 (Table 5). If taken separately, there are variations in students' improvement regarding skills gained from creating Kahoot! games. The result shows that 
in the mechanism category, the respondents were, in most cases, predominantly satisfied with the skills enhancement outcomes. In fact, within this survey, the students' improvement mean rating was $4.00(\mathrm{SD}=0.83)$ for obeying the planned procedures, $3.91(\mathrm{SD}=0.96)$ for logical questions arrangement. With respect to the complex overt response category, the mean rating was $4.03(\mathrm{SD}=0.85)$ for the visually appealing Kahoot! games creation, 4.02 $(\mathrm{SD}=0.74)$ for the logical time allocation for each question, and $3.85(\mathrm{SD}=0.97)$ for the ability to create classroom engagement. Regarding the adaptation category, there were five items included in this cluster, and the students' skills improvement mean rating which ranges from 3.92 to 4.05 . The lowest mean rating belonged to the constructive criticism item $(\mathrm{M}=3.92 ; \mathrm{SD}=0.85)$ and the identification of reliable sources had the highest mean in this category $(\mathrm{M}=4.05 ; \mathrm{SD}=0.84)$. With regard to the last cluster - origination, the item "you can make questions from detailed information" ( $\mathrm{M}=4.15$; $\mathrm{SD}=0.75)$ has the highest mean score and is also the skill which students improve the most. The item "you can create Kahoot! games with compatible audio materials" had the lowest mean in this category $(\mathrm{M}=3.91 ; \mathrm{SD}=1.01)$.

In order to make statistical inference and to test the statistical significance of the main effects, a one-way repeated measures ANOVA test was utilized with group skills as a within-subjects factor and student population as a between-subject factor (first year, second year, and third year). Table 6 below presents the ANOVA results for the between-groups variables and within-groups variables.

Table 6. Effects of Year and Group skill

\begin{tabular}{|l|l|l|}
\hline Effects & $F$-value & $p$-value \\
\hline Year Effects & $F(2,62)=3.646$ & $p=0.032$ \\
\hline $\begin{array}{l}\text { Group skill } \\
\text { Effects }\end{array}$ & $\begin{array}{l}F(2.388,148.066) \\
=0.654\end{array}$ & $p=0.548$ \\
\hline
\end{tabular}

Regarding the year effects, since $p=0.032$ $(p<0.05)$, within this research, we can conclude that the school year of students plays a major role in making remarkable judgments toward skills improvement. With regard to the group skill effects, the $p$-value is 0.548 $(p>0.05)$. The difference in the perceived judgment toward skills gained from making Kahoot! games between participants are not statistically significant.

Table 7 demonstrates the output of Post Hoc Tukey which was conducted to check for any significant differences between each year.

Table 7. Multiple Comparisons

\begin{tabular}{|l|l|l|l|l|}
\hline $\begin{array}{l}(\mathrm{I}) \\
\text { Year }\end{array}$ & $\begin{array}{l}(\mathrm{J}) \\
\text { Year }\end{array}$ & $\begin{array}{l}\text { Mean } \\
\text { Diff (I-J) }\end{array}$ & SE & Sig. \\
\hline 1 & 2 & -0.4848 & 0.23817 & 0.112 \\
\hline & 3 & 0.0542 & 0.19239 & 0.957 \\
\hline 2 & 1 & 0.4848 & 0.23817 & 0.112 \\
\hline & 3 & 0.5390 & 0.20264 & $0.026^{*}$ \\
\hline 3 & 1 & -0.0542 & 0.19239 & 0.957 \\
\hline & 2 & -0.5390 & 0.20264 & $0.026^{*}$ \\
\hline & $* 5 p<.05$ \\
\hline
\end{tabular}

As shown in the table above, the was a significant pairwise difference was found when comparing second year and third year $(p=0.026)$. Results given in Table 6 and 7 taken together show that the school year of the participants affects the judgement toward the improvement of skills gained from making Kahoot! and the statistically significant difference between second year and third year is the main driving force.

Concerning the group skills effects in Creating Kahoot!, no significant effect was found, except for the difference between adaptation and origination at $p=0.077$ which almost reaches a statistical significance level. It can be assumed that there is only a subtle difference in enhancing adaptation skills and origination skills. The results make sense as for the adaptation category, the same skills are well developed through the previous tiers, while the main purposes of the origination level are not only to keep honing the well-developed skills but also to emphasize the creativity of learning 
outcomes. Creating Kahoot! task fits perfectly with the main aims of the origination category. Hence, Kahoot! benefits the origination skills set slightly more than the adaptation one.

\section{Discussion}

A great deal of research has been set out to study those benefits, and likewise this research was conducted. However, the researchers only concentrated on discussing the findings relating to the learners' viewpoints on skill development when they join or create Kahoot! Games inside classrooms.

\subsection{Skills Improved from Playing Kahoot! Games}

Besides a range of positive effects of Kahoot! which has been presented in previous research, this study found that the students also are able to enhance three skill sets, namely people-related skills, conceptual/thinking skills, and personal skills/attributes (NCVER, 2003) [8] as they play Kahoot! games in classrooms.

The findings of this study contribute more additional educational benefits of Kahoot!. While using this tool in class, learners can develop their personal skills and attributes, which are defined as being responsible, resourceful, flexible, able to manage their own time, and having self-esteem. The participants in this study acknowledge that their hands-eyes coordination, quick reflexes, and multi-tasking get better. In addition, they do not feel discouraged when they are falling behind while playing, or when there is nobody listening to their opinions.

Regarding people-related skills, Licorish et al., (2018) [7] point out that 93\% of the participants were agreeable to have interactions with their classmates and lecturers along with engaging themselves in Kahoot! activities. Our study reveals more detailed results. Firstly, students can improve their communication skills. When they are required to play Kahoot! in team mode, they can quickly team up, work well together, and cope with the team conflicts. Furthermore, students are capable of effectively discussing with their teammates to answer correctly. Should their teams not be the leading team, they will encourage each other to keep moving forward. Their interpersonal skills, additionally, are thought to be greatly enhanced in which students not only can patiently listen to their peers' ideas but also assertively persuade the teams to use their right answers or follow their lead. They also can motivate introverted teammates to contribute.

Bicen and Kocakoyun (2018) [1] claim that learners tend to answer as fast as possible without thinking due to the limited time on each question. However, the findings of this research point to the opposite conclusion. With respect to conceptual/thinking skills, it is believed that students can broaden the following attributes: collecting and organizing information, problem-solving, planning and organizing, systems thinking, and so on. As reported by most participants of this study, when they are given limited time to answer the questions, they have managed to quickly find out the key words to quickly understand the main ideas, then apply acquired knowledge to answer correctly. If they give the wrong answers, they will adjust their strategies for better results in the next Kahoot! games.

\subsection{Skills Improved from Making Kahoot! Games}

In a meta-analysis of studies regarding the effects of Kahoot! conducted by Wang and Tahir (2020) [14], it was found that there are $88 \%$ of the studies exploring the students' perception toward using Kahoot! as a learning tool, 39\% of the studies testing the efficacy of Kahoot! in boosting the final exams scores of students, and the remaining $35 \%$ studies focusing on the engagement of students in class. Most of the studies only investigate the playing aspect of Kahoot!. Meanwhile, there is a rare amount of research relating to enhancing students' practical skills through making Kahoot! games. Therefore, the result of this study contributes to a clearer understanding of skills gained from Kahoot!. Our results indicate that through making Kahoot! games the participants can sharpen their critical thinking 
skills such as they can collect information from reliable sources while still ensuring its validity or they can identify where the problem lies and provide constructive feedback if needed. This finding is in line with what was found in the research of El Shaban (2017) [4] exploring Socrative - a reminiscent game-based platform usually used to compare with Kahoot!. Making Kahoot! not only benefits students' critical thinking skills but also enriches their creativity skills as they are able to create Kahoot! games with visually appealing features and compatible audio, apply prior knowledge and combine one from different disciplines to create questions, as well as making a game-based presentation. Additionally, they get to practice analytical skills including making questions from detailed information. These results provide a new insight into skills gained from making Kahoot!.

\subsection{Variability among Different Groups of Skills}

Initially, the researchers had expected that the improvement of three sets of skills (People-related skills, Conceptual/thinking skills, and Personal skills/attributes) is probably equal when the participants play Kahoot! games in class. Nevertheless, according to the result of one-way repeated measures ANOVA (examined in Section 4.1 above), there is a significant difference in the students' perceived judgments of their improvement in the three skill sets. The skill set which the participants felt they have improved the most is conceptual/thinking skills, followed by the people-related skills set, and the personal skills/attributes set is the least enhanced. When performing group comparison between the conceptual/thinking skills and the people-related skills, there is no noticeable difference. Most participants assumed that they could greatly gain/develop every indicated skill belonging to these two sets. This can be plausibly explained by the academic environment at the current research site. With the moderate class sizes of fewer than 30 students, the participants are able to interact easily with their classmates, and lecturers are enabled to design group activities in classrooms in order to enhance students' communication and teamwork skills (people-related skills). Therefore, the participants can sharpen their problem-solving, planning and organizing, and systems thinking skills (conceptual/thinking skills).

\subsection{Variability among Student Populations}

Regarding the year effect of skills gained from making Kahoot!, a comparison between each year was performed. The results indicated that skill improvement varied between each year, but the significant pairwise difference only appeared when comparing the second year and the third year. While there was no noticeable difference when comparing the first year and the second year, the first year and the third year. This proves that the significant difference between the second year and the third year is the main impetus for this variation. Owing to the studying environment of the current research site in which the evaluation of the learning process is conducted to promote critical thinking skills, creativity skills, problem solving skills, and analytical skills. However, while third year students mainly have theoretical subjects, the second year has practical subjects instead. Therefore, they likely have more chances to practice making Kahoot! games.

\section{Conclusion}

Briefly, it is undeniable that there are many educational benefits of adopting Kahoot! in teaching. From lecturers' perspectives, using this learning tool helps increase classroom dynamics and student engagement, while most learners agree that their confidence level and interaction with teachers/peers are improved. Moreover, both those subjects of the teaching process claim that students' final scores are higher as Kahoot! is used for revision. (Bicen and Kocakoyun, 2018; Licorish et al., 2018; Tsymbal, 2018; Wang and Tahir, 2020) $[1,7,12,14]$.

Therefore, this present study was conducted with two-fold aims. First, we want to investigate the educational benefits of Kahoot! in enhancing students' skills and to explore 
their perceptions on how much their skills improve through playing and creating Kahoot! game-based activities. The findings from this study indicates that learners can gain a range of skill sets including people-related skills, conceptual/thinking skills, and personal skills/attributes when they play Kahoot! games in classes. Moreover, four sets of skills (mechanism, complex overt response, adaptation, and origination) are developed as they create Kahoot! games. In addition to the results, the participants' perceived judgment about the improvement of skills gained from joining Kahoot! games between three years (first year, second year and third year) are relatively similar, whereas the development of skills gained from creating Kahoot! games considerably vary between each year.

This research has implications for identifying and giving a clear description of the sets of skills gained from the use of Kahoot! in English-major classes to raise the students' awareness of the benefits gained from this application. Since then, they will pay attention, involve themselves more in class, and be able to creatively adopt Kahoot! in their presentations or other academic activities. The findings also serve as the foundation for teachers to choose which teaching methodologies to utilize to make use of the benefits and to heighten the employability of the students after their graduation.

\section{References}

[1] H. Bicen, S. Kocakoyun, Perceptions of Students for Gamification Approach: Kahoot as a Case Study, International Journal of Emerging Technologies in Learning, Vol. 13, No. 2, 2018, pp. 22, https://doi.org/10.3991/ijet.v13i02.7467.

[2] B. S. Bloom, Taxonomy of Educational Objectives, Handbook: The Cognitive Domain, David McKay, New York, 1956.

[3] B. Budiati, ICT (Information and Communication Technology) use: Kahoot Program for English Students' Learning Booster, Proceedings Education and Language International Conference, Vol. 1, No. 1, 2017, pp. 178-188.
[4] A. El Shaban, The use of Socrative in ESL Classrooms: Towards Active Learning, Teaching English with Technology, Vol. 17, No. 4, 2017, pp. 64-77,

http://cejsh.icm.edu.pl/cejsh/element/bwmeta1.element. desklight-87cb1955-f44b-454a-b455-4b6d0fbe36c3.

[5] K. Kechagias, Teaching and Assessing Soft Skills, $1^{\text {st }}$ Second Chance School of Thessaloniki, Thessaloniki, 2011.

[6] F. D. Kinder, J. M. Kurz, Gaming Strategies in Nursing Education, Teaching and Learning in Nursing, Vol. 13, No. 4, 2018, pp. 212-214, https://doi.org/10.1016/j.teln.2018.05.001.

[7] S. A. Licorish, H. E. Owen, B. Daniel, J. L. George, Students' Perception of Kahoot!'s Influence on Teaching and Learning, Research and Practice in Technology Enhanced Learning, Vol. 13, No. 1, 2018, https://doi.org/10.1186/s41039-018-0078-8.

[8] NCVER, Defining Generic Skills: At a Glance, National Centre for Vocational Education Research, https://www.ncver.edu.au/data/assets/file/0020/4457 nr2102b.pdf/, 2003 (accessed on: April 15 ${ }^{\text {th }}, 2021$ ).

[9] T. T. Nguyen, T. Yukawa, Kahoot with Smartphones in Testing and Assessment of Language Teaching and Learning, the Need of Training on Mobile Devices for Vietnamese Teachers and Students, International Journal of Information and Education Technology, Vol. 9, No. 4, 2019, pp. 286-296, https://doi.org/10.18178/ijiet.2019.9.4.1214.

[10] N. Pachler, B. Bachmair, J. Cook, Mobile Learning: Structures, Agency, Practices, Springer US Publisher, New York, 2010.

[11] C. M. Plump, J. LaRosa, Using Kahoot! in the Classroom to Create Engagement and Active Learning: A Game-based Technology Solution for E-learning Novices, Management Teaching Review, Vol. 2, No. 2, 2017, pp. 151-158, https://doi.org/10.1177/2379298116689783

[12] S. Tsymbal, Gamified Training Sessions as Means of Enhancing Students' Motivation in Learning English, Psychological Journal, Vol. 4, No. 7, 2018, pp. 151-161, https://doi.org/10.31108/1.2018.7.17.10.

[13] Z. Turan, E. Meral, Game-based Versus to Non-game-based: The Impact of Student Response Systems on Students' Achievements, Engagements and Test Anxieties, Informatics in Education, Vol. 17, No. 1, 2018, pp. 105-116, https://doi.org/10.15388/infedu.2018.07.

[14] A. I. Wang, R. Tahir, The effect of Using Kahoot! for Learning - a Literature Review, Computers and Education, Vol. 149, 2020, https://doi.org/10.1016/j.compedu.2020.103818. 